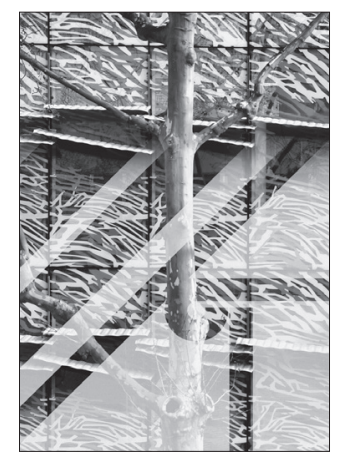

DOI: $10.37190 /$ arc210106

\title{
Michał Kwasek*
}

\section{Conservation aspects of cast-iron platform shelters on the example of Vistula Pomerania railway stations}

\section{Introduction}

The development of railroads, which took place in the $2^{\text {nd }}$ half of the $19^{\text {th }}$ century, significantly changed people's lives and the European countries' economies at that time. Numerous railroad lines connected significant cities, facilitating the exchange of goods and people's transportation, even over long distances. This means of transport, modern for those times, contributed to the intensive development of agglomerations. It significantly expanded markets for industry ${ }^{1}$ and became an integral part of their economies. However, the architecture and urban planning of cities also transformed. It was a period when many public buildings were erected. They were given the features that characterized representative buildings. Such an attitude can also be found in the emerging railroad infrastructure. Railroad buildings, especially those used for passenger service, were often given monumental or decorative forms, referring in the $2^{\text {nd }}$ half of the $19^{\text {th }}$ century to the Classical, Renaissance, or Gothic periods [1, pp. 27-29], [2, pp. 380, 394]. Presumably, the activities undertaken were also intended to demonstrate the new technical possibilities of the time and, through their aesthetics, to enhance the railroad's public perception. Initially, as a novelty, the railroad could arouse resentment among society ${ }^{2}$

* ORCID: 0000-0002-3485-7219, Faculty of Architecture, Gdańsk University of Technology, e-mail: michal.kwasek@pg.edu.pl

1 Before establishing iron railroads, the natural river routes were the most effective means of transport for all kinds of goods. They had significant influence on the shape of the market areas of crafts and industry.

2 Similar activities, aimed at reducing the initial reluctance of city dwellers towards the new urban infrastructure - tramways - were carried out during the construction of their catenary networks, giving the catenary poles very decorative forms $[3$, p. 58$]$.
$[4$, p. 39]. The construction of linear infrastructure was the cause of the first land expropriations in history [1, p. 22], which may have compounded public antipathy to new city facilities.

Platforms became an inseparable element of railroad stations, in the parts dedicated to passengers. To increase travellers' comfort, they were often covered with roofs sheltering from rain or snow. By connecting platforms with station buildings (usually by underground passages), passengers were protected against the weather conditions mentioned above from the moment they entered the station until the end of their journey. The most significant stations received highly decorative platform shelters, both on double- and single-edge platforms. Rows of decoratively painted cast-iron columns were placed rhythmically in sometimes very long $(300 \mathrm{~m})$ sequences. The canopies supported on them were placed at such heights so that the shielding structures were not overwhelming for the travellers and did not impede boarding the trains or disembarking from them. The slenderness of the supports used in the shelters gave a sense of lightness to the entire structure. The innovative $19^{\text {th }}$-century solutions described here are a testimony to an era long gone. Despite the cast iron durability from which the shelters were built, it is still necessary to take care of their technical condition and, above all, to be aware of their value.

This article presents technical and architectural solutions of selected examples of this type of railroad platform shelter found in the Vistula Pomerania. References of foreign realizations from the $19^{\text {th }}$ century are also included. This analysis concerns a crucial element in the history of architecture, between technical and representative buildings. Even though the subject of railroad history in the area of contemporary Poland has been described in a relatively large number of works, e.g., [5]-[7], they hardly ever refer to (or omit) the issue of platform shelters. 
Many papers deal only with aspects of the functioning and the impact of railroad stations on past and present urban structures, e.g., [8], [9]. Also, in the literature that considers the history of the development of railroad construction worldwide, e.g., [2], [10]-[12], the scope of the subject matter undertaken in this article remains vaguely recognized. The few mentions of the $19^{\text {th }}$-century railroad platform shelters are insufficiently detailed and sometimes misleading ${ }^{3}$. Our present attempt to introduce and assess this issue may contribute to highlighting the significant values of these objects and the necessity of their preservation.

\section{Characteristics of cast-iron platform shelters and their functional and structural significance}

Cast-iron structures of platform shelters have been created since 1830 [12, p. 9], but they became widespread in the $2^{\text {nd }}$ half of the $19^{\text {th }}$ century. This was possible, among other things, due to the development of engineering theories and the elaboration of new technologies for producing structural elements at that time. Using metal, including cast iron, it became possible to obtain impressive and robust building structures [13] with large spans and an unprecedented form ${ }^{4}$. The prefabrication of structural components resulted in considerable shortening of the construction time. Simultaneously, the possibility of obtaining repeatable products in industrial production exceeded the possibilities of craftsmanship many times over.

The earliest type of roofing used in railroad stations was platform halls. They were the most popular, particularly in Western Europe. They were sometimes spectacular, usually arched or frame structures and their spans made it possible to cover all the platforms at once. Thus, they provided shelter for both travellers and trains ${ }^{5}$. The further towards the east of the continent, the less popular such a solution was $^{6}$, and platform shelters took their place. This simple roofing was a somewhat later solution, invented in 1849 for cost-saving reasons [12, p. 31]. They were two to three times cheaper variant of roofing [12, p. 37], covering single platforms, both those adjacent to the station buildings (single-edge) and island (double-edge). Various types of solutions of cast-iron platform shelters, including those with untypical forms, are presented, among others, in a German construction handbook from the beginning of the $20^{\text {th }}$ century $[14, \mathrm{pp} .306,344]$.

\footnotetext{
3 Sometimes structures erected using cast-iron components are considered as made of steel, or there is no differentiation between later riveted solutions.

4 Addis [10, pp. 294, 295] demonstrates the correlation between the growth of railroads worldwide and the increased use of cast iron and wrought iron in construction, even in areas far distant from steelworks and foundries. These new materials also gave rise to the construction of railroad buildings with large roof spans from 1850 onwards [10, p. 291].

5 As Wesołowski [12, p. 30] proves, the original reason for using coverings at railroad stations was primarily to protect rolling stock, not passengers

6 They were also found on the territory of present-day Germany, but their use was, in most cases, relatively late [12, p. 16].
}

The vast majority of columns supporting such canopies were made of cast iron ${ }^{7}$. In addition to its good structural parameters, this material's castability enabled very aesthetic forms to be obtained, particularly decorative in the parts of the column capitals. Therefore, the structure was also a decorative element of the platforms. The chosen material and production method ensured that the castings also fulfilled many practical demands. A significant advantage of cast iron is its durability and atmospheric resistance, providing better corrosion resistance [15]. The high strength and castability made it possible for the designed structural and architectural requirements of castiron columns to be maintained in each casting. These elements have small cross-sectional dimensions compared to elements with the same structural parameters made of other materials. As a result, they are highly slender and therefore delicate in form. Nevertheless, they have a substantial load-bearing capacity margin. Many numerical and strength tests of cast-iron columns supporting ceilings even in multi-story buildings confirm that [16], [17].

Platform shelters, though initially erected as cheaper versions of platform roofing, over time began to displace the halls, which appeared too dark and too expensive to maintain (the need for conservation). In the last decade of the $19^{\text {th }}$ century, numerous criticisms of these large structures began to be expressed. Simultaneously, the positive aspects of small shelters were pointed out, as they provided sufficient or even better (compared to high halls) protection of travellers from the weather. They were cheaper and ensured better conditions such as ventilation (air circulation removing smoke released from locomotives), lighting, and acoustics. After several decades, the construction of roofing over the halls was destroyed by smoke [12, pp. $56,57]$. As a result, from the beginning of the $20^{\text {th }}$ century (sometimes the end of the $19^{\text {th }}$ century), large platform halls were often dismantled and replaced with continuous shelters [12, pp. 61-63], [1, p. 37]. Newly built objects were usually constructed as one- or two-column riveted structures, which was a sign of "progress in railway station architecture" $[12, \text { p. } 63]^{8}$. Consequently, railroad stations that, for reasons of location or inadequate funding, gained platform shelters instead of large halls in the $2^{\text {nd }}$ half of the $19^{\text {th }}$ century can now stand proud with highly ornamental cast-iron structures that are aesthetically far superior to steel riveted shelters.

\section{Cast-iron platform shelters in Vistula Pomerania}

In Vistula Pomerania cast-iron platform shelters are located at the stations: Gdańsk Główny, Sopot, Malbork, Lębork, Bydgoszcz Główna, Toruń Główny, Elbląg. The examples selected and presented in the article are at stations of the railroad line that reached Pomerania in 1852. It was an extension of Berlin's line, built successively from

\footnotetext{
${ }^{7}$ Because of its strength properties, cast iron was mainly used to create parts under compression, such as columns.

8 Prussia was an exception in that trend. They often did the opposite there, erecting new halls as late as 1960 [12, pp. 64, 65].
} 
1841 to Bydgoszcz, Tczew, and further to Gdańsk. In 1857 it also reached Königsberg (via Malbork). Its construction was completed in 1873 in what is now Chernishevskoye. This railroad, the longest in Prussia (about $750 \mathrm{~km}$ ), was called "Ostbahn". In 1870 a line connecting Gdansk with Słupsk (via Sopot) was built. Additionally, in the 1870s and $1880 \mathrm{~s}$, routes connecting Tczew with Iława, Chojnice and Grudziądz were established [1, pp. 22-24], [7, p. 12].

As mentioned, shelters were a less representative solution for platform roofing. In Vistula Pomerania, a relatively new eastern province of Prussia at that time ${ }^{9}$, they were used quite commonly since the stations situated there were not of great economic and political interest. It was a standard, cost-saving procedure of the authorities in less significant locations ${ }^{10}$ [12, p. 35]. Nevertheless, to give platform shelters a decorative and aesthetic appearance, cast-iron construction elements embellished with historical details were used at the train stops of larger cities. The solutions presented in the following text originate from the $2^{\text {nd }}$ half of the $19^{\text {th }}$ century ${ }^{11}$.

\section{Construction, architecture, and conservation of cast-iron platform shelters from selected examples of the Vistula Pomerania}

The standard type of shelter for double-edge platforms is the gable roof (Fig. 1). It is a self-sufficient structure. Cast-iron pillars contain decorative capitals and bases. At the top, they are provided with endings that lengthen the support of the wooden rafters. This also leads to an increased stiffening of their connection with the pillars. The form of this part of the columns imposes the angle of the roof inclination. The cast-iron supports are paired to form load-bearing frames, usually set rhythmically at 6-7.5 $\mathrm{m}$ intervals. The elements that bind the pillars together are the wooden rafters. They are the supports for the roof purlins laid perpendicularly on them. The frames are reinforced with metal ties attached above the heads of the columns. To reduce the deformation of these horizontal bars, they were hung to the rafters at mid-span. Such a construction solution was used at least as early as 1850 $\left[12\right.$, p. 211] and is representative of the $2^{\text {nd }}$ half of the $19^{\text {th }}$ century. It was applied at many stations of the railroad line connecting Königsberg with Berlin. They were also made in Gdańsk Główny and Sopot.

At the main station of Pomerania's capital city, the canopies of platforms 2-5 are historical examples of cast-iron shelters with a large, as for such objects, roof angle. It is about 20 degrees (the slope of the shelters used on this railroad route was usually about 6 degrees) and may derive

\footnotetext{
9 At the time the railroad was built, the area described was under Prussian rule.

10 This also referred to present-day Poland areas, which were under other occupations, including the Warsaw-Vienna Railway, on the route of which even the largest stations were more modest, and their platforms equipped only with shelters [1, p. 34].

11 The buildings of the current Main Railway Station in Gdańsk do not originate from when the railroad line was built in the city. The construction of this complex of buildings began in 1894 and lasted until $1900[18$, p. 261]
}

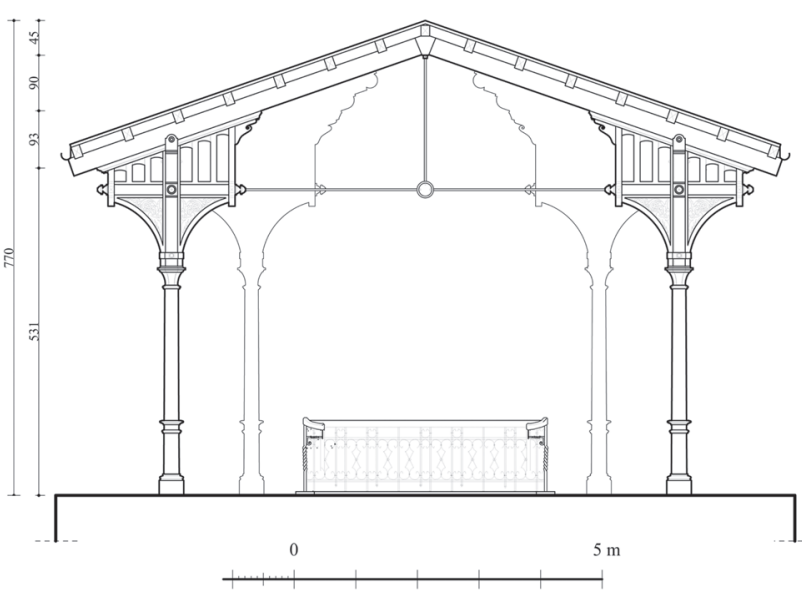

Fig. 1. Gdańsk Główny railway station, cross section through a cast-iron shelter on platform No. 2, inventory 2014 (source: collections of KTPPA, WA PG, elaborated by: A. Urbańska, M. Wachowiak, A. Wyżlic, M. Kwasek)

Il. 1. Gdańsk Główny, dworzec PKP,

przekrój poprzeczny przez wiatę o konstrukcji żeliwnej na peronie 2, inwentaryzacja, stan z 2014 r. (źródło: zbiory KTPPA, WA PG,

oprac. A. Urbańska, M. Wachowiak, A. Wyżlic, M. Kwasek)

from the large width of the platforms and thus the long span (distance between the pillars) of the frame, which is as much as $8.2 \mathrm{~m}^{12}$. Consequently, these shelters reach $7.7 \mathrm{~m}$ in height, and the horizontal ties are also fixed in a non-standard way - at $2 / 3$ of their height (Fig. 1). These canopies range in length from less than $100 \mathrm{~m}$ to just over $200 \mathrm{~m}$. On platform two (the most extended authentic shelter), the decorated cast-iron columns are unusually arranged in four rows. The vast majority of them are situated at a standard distance from the platform's edge ${ }^{13}$. However, in places where stairs lead to the platform, the cast-iron pillars were moved $1.3 \mathrm{~m}$ further from the platform's edge (Fig. 2). The purpose of this was to create more space for travellers to move around where, due to the location of the stairs, there was less space. The use of the same cast-iron pillars (of equal height) while maintaining the same roof plane required additional elements to raise the rafter support line. For this purpose, a set of wooden beams was used (Fig. 2).

In the $2^{\text {nd }}$ decade of the $21^{\text {st }}$ century, modernization works started at this railroad station. They also affected the platforms. They were performed successively in order to allow the station to continue functioning. During the remodelling of platform No. 3 in 2013-2014, its historic shelter was transformed. Several of the cast-iron and

12 The lower the roof inclination, the greater the horizontal component of the forces acting on the structure - in this case, transmitted by the tie rods. It, therefore, seems appropriate to widen the angle of the roof slope to increase the load on the columns, which are already oversized.

13 In the $19^{\text {th }}$ century, during the construction of such roofings, the distance of columns from the edge of the platform was regulated (in Great Britain and the USA - min. $1.8 \mathrm{~m}$. In Prussia - the distance from the axis of the tracks to the axis of the columns had to be $3 \mathrm{~m}[12$, pp. 49, 50]). Example guidelines are available, among others, in: [14, p. 288]. 


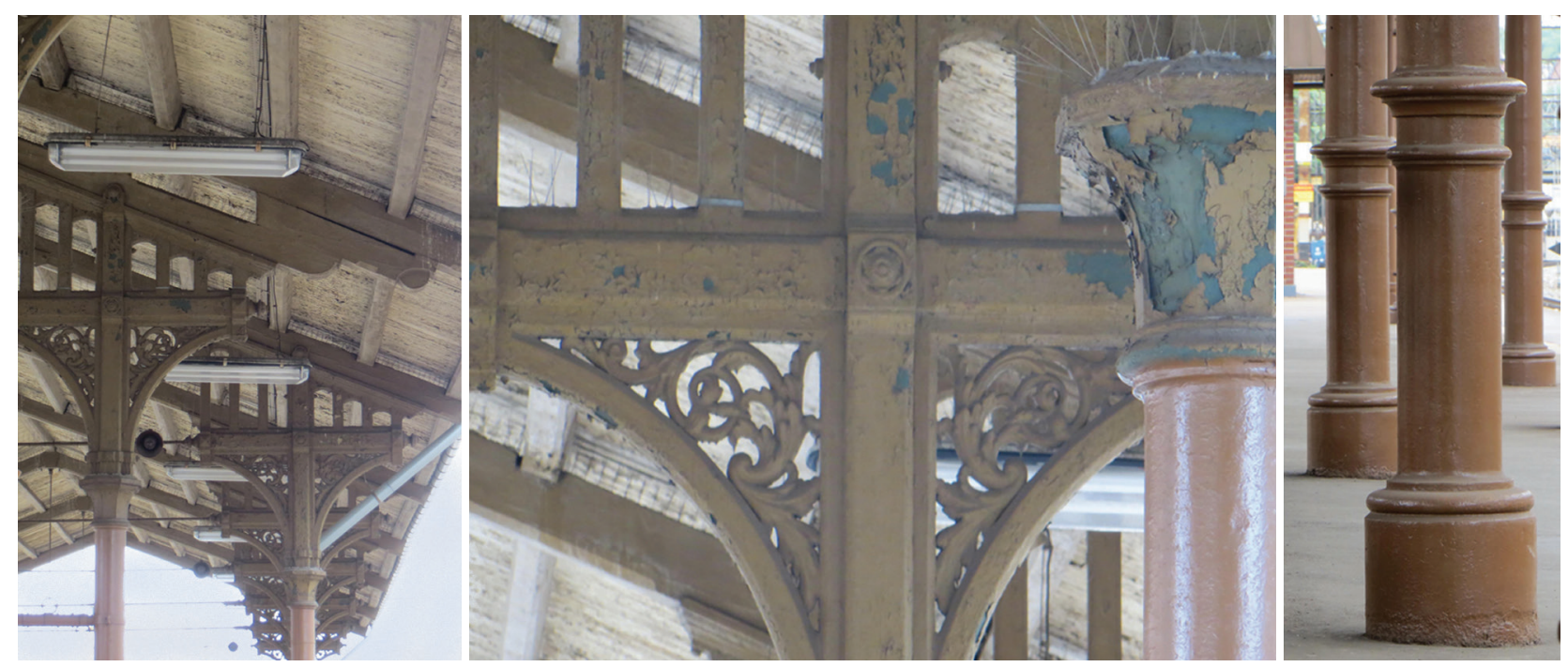

Fig. 2. Gdańsk Główny railway station, platform No. 2 roofing, 2012 (photo by M. Kwasek)

Il. 2. Gdańsk Główny, dworzec PKP, zadaszenie peronu 2, stan z 2012 r. (fot. M. Kwasek)

wood frames had their transverse spacing of posts reduced. The shelter on the north side was extended ${ }^{14}$. The five metal structural frames installed there have been given a simplified form reminiscent of the historical one. The new elements were to receive a distinctive colour, and the platform's floor was to be differentiated by the material to emphasize the various times of construction. At present, it is not definite whether this idea was not carried out or whether subsequent actions obliterated the distinction. By 2017, the shelters on other Gdańsk platforms underwent essential repair works, primarily to improve their visual condition. These mainly included the lower parts of the poles and entailed cleaning them and applying new paint layers (Fig. 2). Between 2014 and 2017, another coat of paint was applied to the cast-iron structure, which referred to the original one - dark blue. It was noticeable in the upper (unpreserved) parts of the columns (Fig. 2) and was further confirmed by stratigraphic examination in $2014^{15}$. Comprehensive works were undertaken in 2017 to the platform 1 and platform 2 shelters have involved removing their roof sheathing and the cast-iron supports on the platforms, which were out of service for the time.

The pillars have been subject to conservation works. They were thoroughly cleaned of all paint coatings, the original colours were restored, and areas of pitting caused by corrosion were filled in. In 2018, the pillars were repositioned to their former places (Fig. 3), and the wooden elements were replaced with new ones. These were conservative measures, enabling the continuation of such a unique structure, restoring their original appearance from the turn of the $20^{\text {th }}$ century. The shelter of platform 1 is a contemporary implementation from the early 1990s. As with the added pillars of platform 3, their upper parts refer to the

14 Based on the documentation provided by the Provincial Office for Monuments Protection in Gdańsk.

15 Based on the documentation provided by the Provincial Office for Monuments Protection in Gdańsk. historical design solution. The steel poles have the same diameter as their counterparts from other platforms. Nevertheless, they have been given a simple form deprived of ornamentation. Thus the pillar shafts do not even contain a separate base. The pillar capital has been simplified geometrical, using a historical technique (cast iron).

At the Sopot railroad station, there are about $200 \mathrm{~m}$ long cast-iron platform shelters. Their form is resembling the ones implemented in numerous S-Bahn stations in Berlin, among others in Yorkstraße, Ostkreuz, Schönhauser Allee, S Wannsee Bahnhof, Potsdam Griebnitzsee and many others (Fig. 4). Occasionally they differ in dimensions, details - the form of decorative capitals or bases, the way of suspension, and the fastening of metal ties ${ }^{16}$. However, structurally and architecturally, they are similar solutions. As in the Berlin's stations mentioned above, the Sopot shelters are characterized by a significantly reduced roof inclination compared to the later construction in Gdańsk - only about 6 degrees. These structures are much lower than in Gdańsk (4.5-4.7 m) and have a shorter span of the metal and wooden frames $(5.2-5.5 \mathrm{~m})$. Nonetheless, only one of the presented Sopot shelters is an original structure (Fig. 5). It is located on the platform currently used by suburban trains (SKM). During the 2008-2010 modernization and restoration works, the cast-iron pillars were repositioned, the historic character of the floor was reconstructed, and based on the stratigraphy examination of the pillars, their cream-golden coloration, dating back to the 1870 s, was restored ${ }^{17}$.

A nearly identical shelter, located on the long-distance platform, is a structural and architectural copy of the $19^{\text {th }}$-century cast-iron construction (Fig. 6). It also applies a similar colour palette, which makes its contemporary

16 For example, at Yorkstraße station, metal ties were omitted, despite using the same cast-iron pillars (due to their short spacing).

17 Based on the documentation provided by the Office of the Monuments Conservator in Sopot City Hall. 

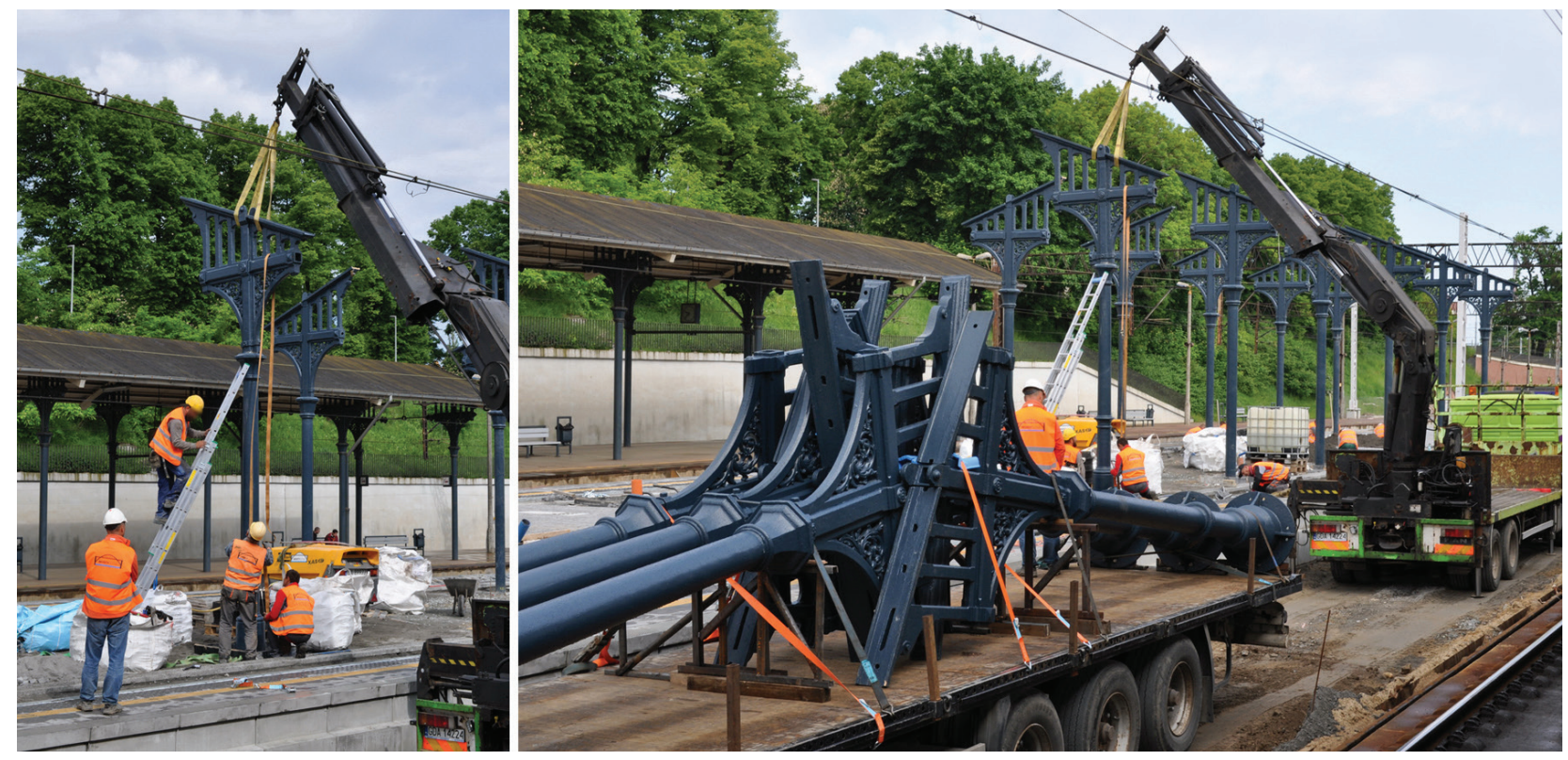

Fig. 3. Gdańsk Główny railway station, works of reassembly of the renovated cast-iron pillars of platform No. 2, 2018 (photo by M. Kwasek)

Il. 3. Gdańsk Główny, dworzec PKP, prace przy ponownym montażu odnowionych żeliwnych słupów zadaszenia peronu 2, stan z 2018 r. (fot. M. Kwasek)
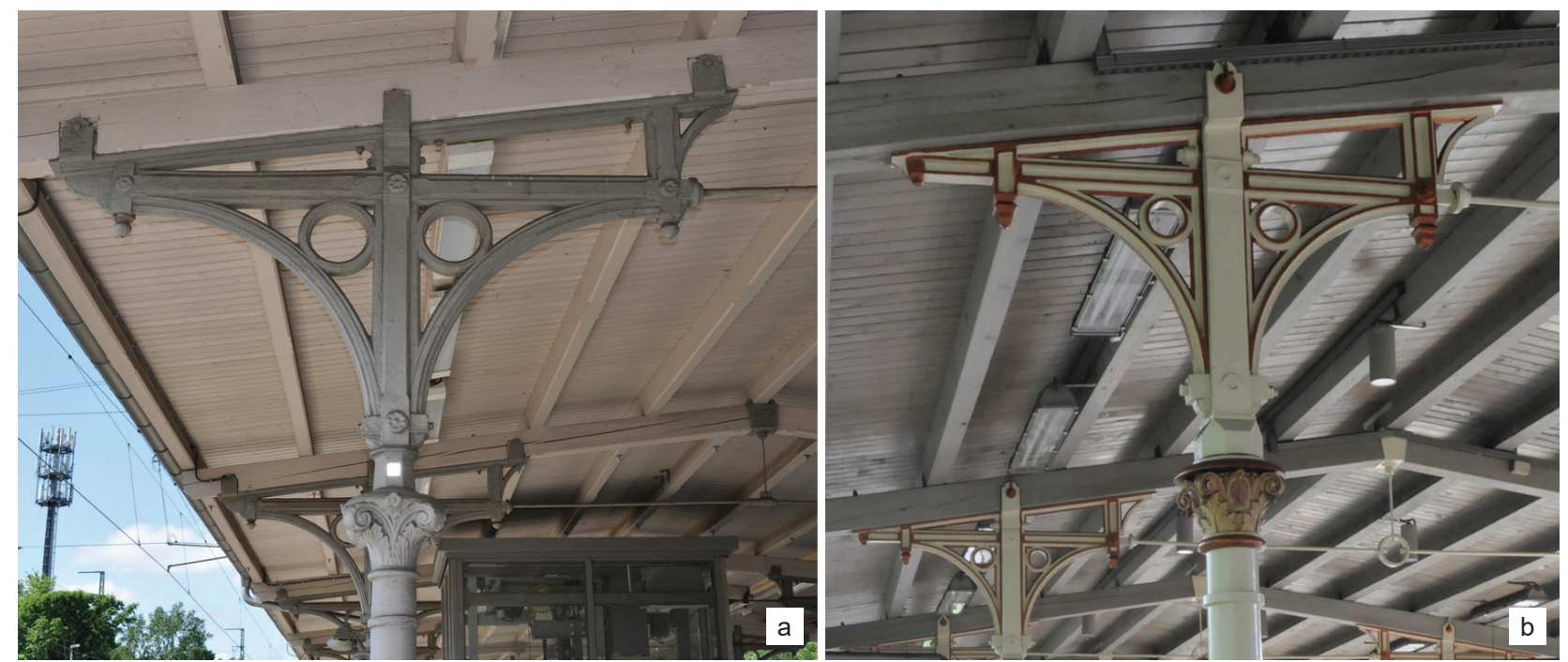

Fig. 4. Comparison of the upper parts of cast-iron columns supporting platform shelters: a) Berlin S Wannsee Bahnhof, 2019, b) Sopot, 2020 (photo by M. Kwasek)

Il. 4. Porównanie górnych partii żeliwnych słupów podpierających zadaszenia peronowe: a) Berlin S Wannsee Bahnhof, 2019 r., b) Sopot, 2020 r. (fot. M. Kwasek)

origin hardly recognizable at present. It is distinguished only by individually designed details of the pillar capitals containing maritime motifs. This platform was covered by a double-braced shed of riveted steel construction until ten years ago, presumably dating from the early $20^{\text {th }}$ century. It was demolished in 2011. At the same time, the city authorities acquired the historical structural elements from the railroad company. Some of them have been recently renovated and installed as small architecture in front of the Sopot railway station building. Solutions in which authentic elements of railroad infrastructure are used in ur- ban space are currently encountered in many cities, whose growth was strongly related to railroad development, e.g., in Berlin or Tczew (Poland).

The railroad station in Malbork presents an intermediate approach between the conservative works in Gdańsk and the Sopot creation, with a strong reference to historical forms. In this facility, a row of cast-iron pillars supports a pent roof, added to the station building from the platforms' side (Fig. 7). During the renovation works carried out in 2014, all elements of this structure were cleaned and painted. Additionally, the pillars were provided with 

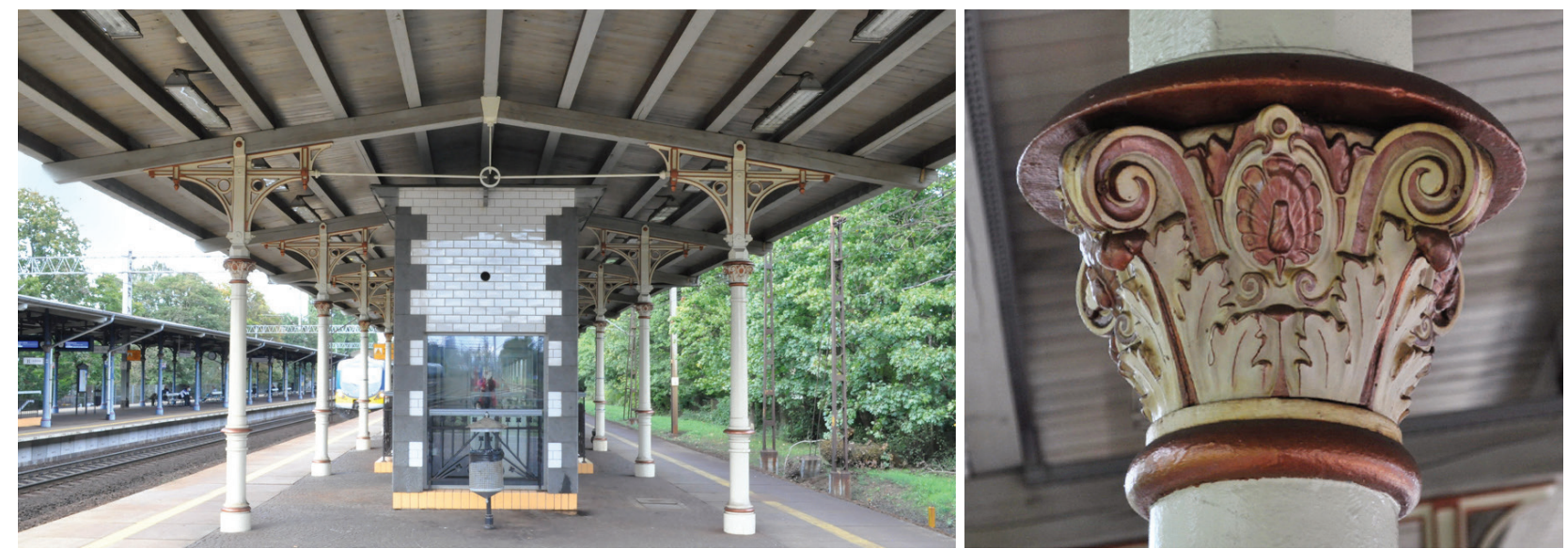

Fig. 5. Sopot railway station, general view and construction detail of the $19^{\text {th }}$-century cast-iron platform shelter on the platform of the SKM (Rapid Urban Railway), 2020 (photo by M. Kwasek)

Il. 5. Sopot, dworzec PKP, widok ogólny i detal konstrukcji XIX-wiecznej żeliwnej wiaty peronowej na peronie Szybkiej Kolei Miejskiej, $\operatorname{stan}$ z 2020 r. (fot. M. Kwasek)
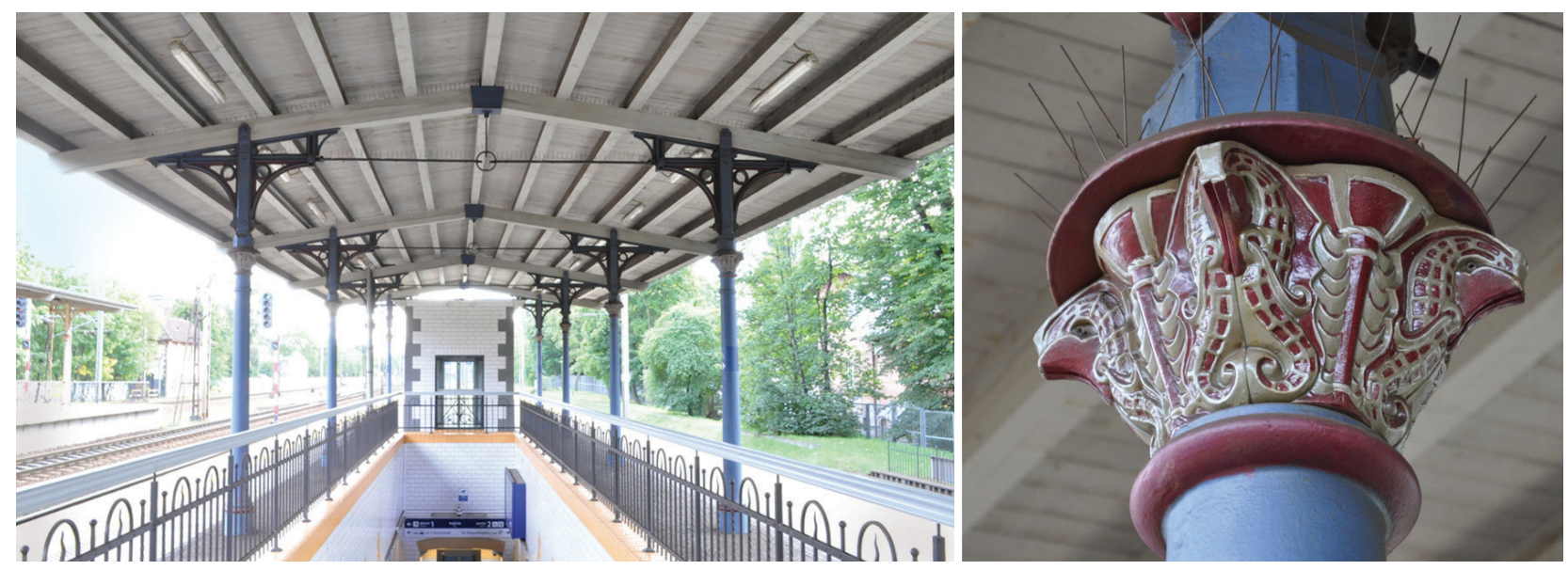

Fig. 6. Sopot railway station, general view and construction detail of the platform shelter on the long-distance platform created about 2011, the state in 2020 (photo by M. Kwasek)

Il. 6. Sopot, dworzec PKP, widok ogólny i detal konstrukcji wiaty peronowej na peronie dalekobieżnym zrealizowany około 2011 r., stan z 2020 r. (fot. M. Kwasek)

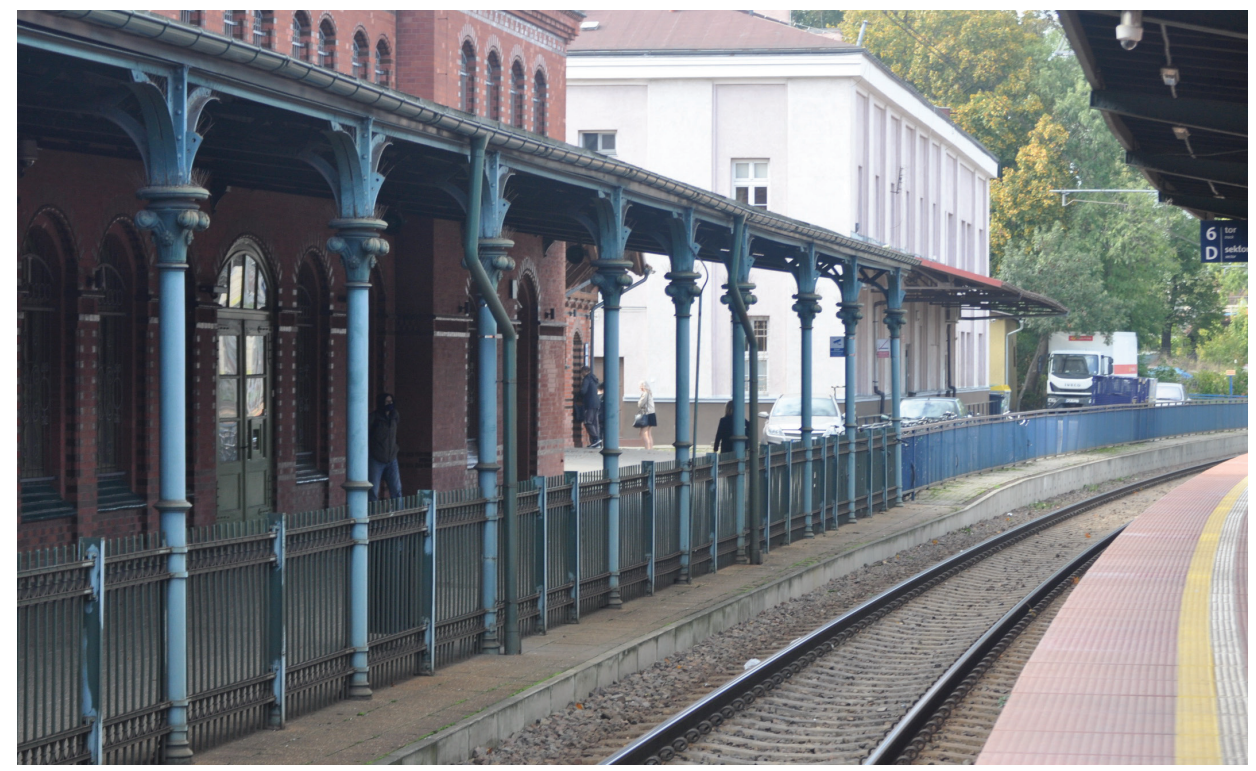

Fig. 7. Malbork railway station, single-pitched platform shelter with cast-iron pillars,

the state in 2020

(photo by M. Kwasek)

Il. 7. Malbork, dworzec PKP, jednospadowa wiata peronowa o żeliwnych słupach, stan z 2020 r. (fot. M. Kwasek) 
Fig. 8. Malbork railway station, detail of the head of the cast-iron pillar of the platform shelter before and after the installation of the decorative overlays:

a) the state in 2014

b) the state in 2020

(photo by M. Kwasek)

Il. 8. Malbork, dworzec PKP, detal głowicy żeliwnego słupa wiaty peronowej przed zamontowaniem dekoracyjnych nakładek i po zamontowaniu: a) $\operatorname{stan}$ z 2014 r., b) $\operatorname{stan}$ z 2020 r (fot. M. Kwasek)
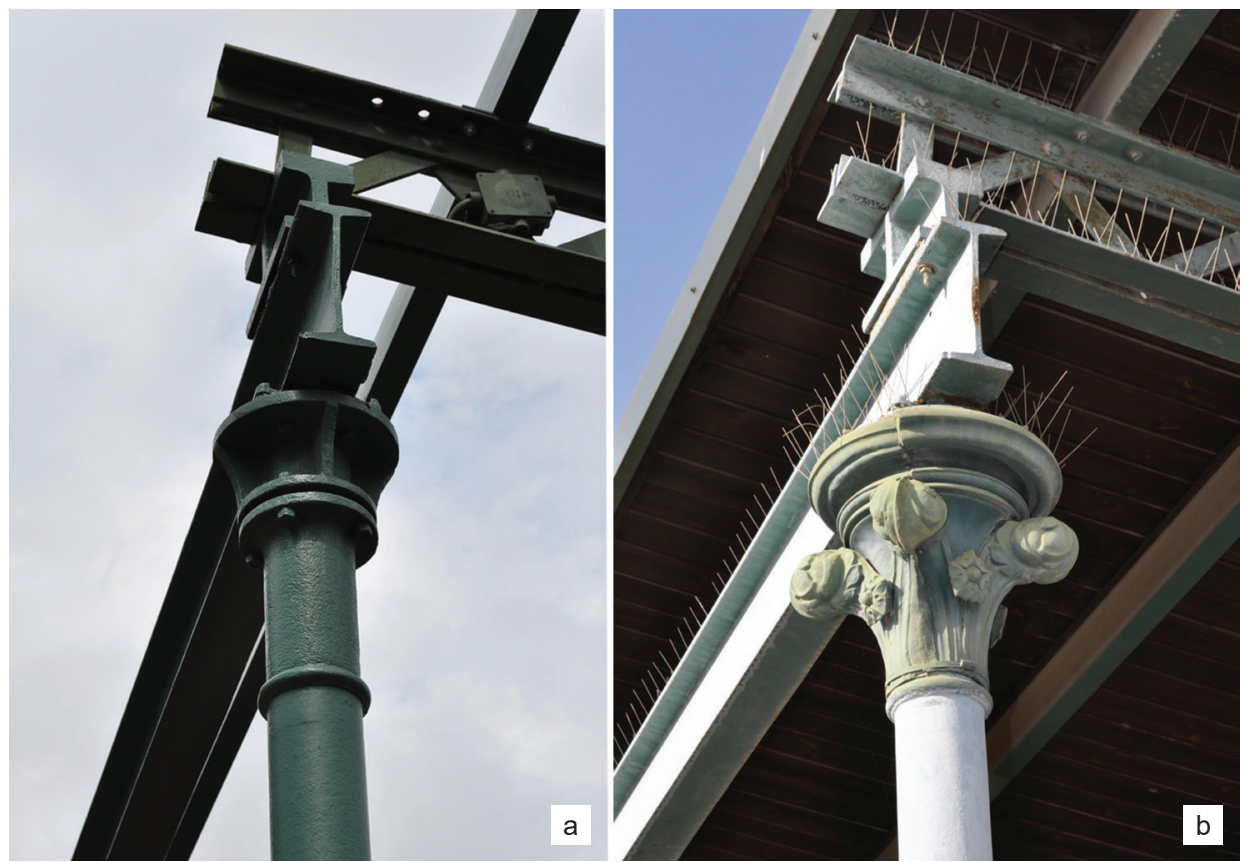

decorative capitals bonnet (Fig. 8). They replaced the originals, which presumably were present here and were deteriorated over the decades ${ }^{18}$. The contemporary form of the overlays applied is a relatively liberal reference to those used in $19^{\text {th }}$-century capital realizations, and its contemporary origin is recognizable without difficulty. Nevertheless, the material and quality of workmanship are not of the highest standard. They were made of plastic or thin sheet of non-ferrous metal ${ }^{19}$. These materials have aged differently from the painted surfaces of the metal pillar (Fig. 8). While the fastening systems of the cast-iron capital elements remain in most cases invisible, the described bonnets in Malbork were attached to the column using steel clamps. Undoubtedly, such a method of assembly is exposed to easier destruction and may also have a negative impact on the aesthetics of the solution. Commendable in this realization is the decision to restore the pillars' incomplete form and the use of patterns indicating their non-authentic origin. To some extent, the selection of material applied may be justified by the nowadays difficulty of replicating a historic building fabric - in preference to a readily available plastic. Nevertheless, as the examples illustrate:

- the use of material more durable and resembling the original is possible (Sopot),

- using a synthetic product is not advisable (Malbork).

\section{Conclusions}

Cast-iron platform shelters, as durable objects, are still in service today. Presumably, due to their long-term usefulness, they have not been subject to disassembly, as many

18 The form of the upper part of the column (Fig. 8, condition as of 2014), with an isolated section (with the use of a minor, simple band), indicates that cast-iron decorative bonnets have initially been mounted there, which were usually attached around the shaft to form decorative capital.

19 The element does not react to a magnet. transport infrastructures have been in recent decades [19, p. 125]. In most instances, they underwent only essential works to enhance their visual appearance until recently, and their preservation was conditioned, inter alia, by the superior properties of cast iron. The precise extent of damage to Poland's platform shelters due to the destruction of World War II is unknown ${ }^{20}$. Thankfully, a large part of them evaded destruction during military operations. Such a situation is particularly noticeable in Gdańsk, where the entirely ruined historical city district is located in a relatively short vicinity of the railroad station. As the literature analysis showed, platform shelters with cast-iron pillars were rare in Western Europe. However, although they were built much more frequently in its central and eastern parts, their number is relatively small for economic concerns. The replacement of this type of structure with a variant built of steel riveted elements limited the construction of cast-iron shelters (mainly in the $2^{\text {nd }}$ half of the $19^{\text {th }}$ century). Therefore, they are unique objects, distinguished by their aesthetics against the background of later solutions. Contemporary, numerous modernization works undertaken at railroad stations favour the renovation of these historic shelters. Cast-iron elements are usually protected and treated in order to restore their former magnificence. As numerous instances prove, it is also relatively easy to restore their historic colours ${ }^{21}$. Their ornamental form is slightly preferred over riveted, wooden, or reinforced concrete structures. The necessity of preserving platform shelters,

20 They were not included among the more important railroad facilities that were subjected to such analysis in 1945. It is only known that Poland's railroad stations' destruction (service buildings including) ranged from about $28 \%$ to about $40 \%$, depending on the region [7, p. 25]. The war activities certainly contributed to the demolition of the old railroad station in Tczew, and thus, no cast-iron platform shelters are preserved there. There may be more such undocumented cases.

21 It is required to perform a stratigraphy examination in every case. 

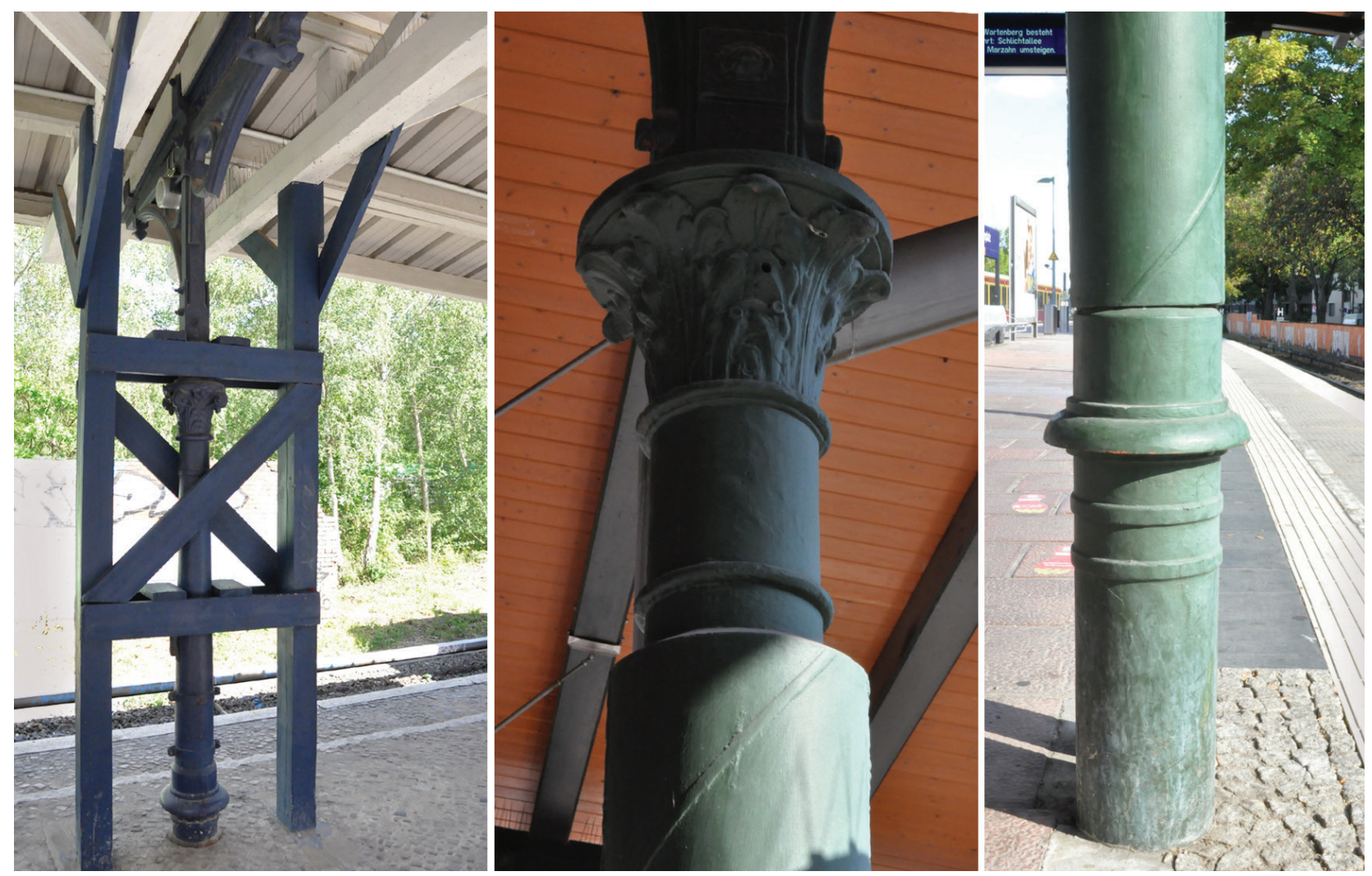

Fig. 9. Berlin, examples of repair work on cast-iron columns of platform shelters in S-Bahn stations, the state in 2019 (photo by M. Kwasek)

Il. 9. Berlin, przykłady prac naprawczych żeliwnych słupów wiat peronowych na stacjach S-Bahn, stan z 2019 r. (fot. M. Kwasek)

which were historically built using various materials, has been noticed by the scientific and heritage preservation communities, e.g., [20], [21]. However, their continuation is most often secured through legal protection. As the example of the Frankfurt (am Main) Hauptbahnhof station demonstrates, even considerable structural modifications can be carried out while respecting and preserving the authentic cast-iron structural components [21, p. 23].

Potentially the most serious difficulties that may occur during the exploitation of a cast-iron structure may be generated by possible reparatory works. As indicated by unsuccessful attempts to repair cast-iron pillars [22, p. 58], identifying an adequate intervention method is then crucial. Similarities in the applied forms, material, and construction solutions of cast-iron platform shelters in Poland and abroad permit analogous and proven repair means. In Germany, techniques have been developed that allow for the temporary or permanent strengthening of such damaged pillars, using additional external metal jackets or an auxiliary wooden structure (Fig. 9). The conducted experimental studies indicate that cast-iron columns' reinforcement is also possible using composite fibres, which does not significantly affect the columns' aesthetics [23].

As outlined in this article, the approach to conservation efforts can be significantly different. It is essential to select the proper material, and even before the works - to perform a stratigraphic examination of the historical painting coats. Such actions will make it possible to enhance the authenticity factor. Works on neighbouring platforms, which do not have shelters with cast-iron pillars, e.g., in the process of station extension or modernization, may take various forms. It is advisable to strive for consistency of new or reconstructed objects with authentic, $19^{\text {th }}$ century realizations. Unquestionably, it should not obliterate the boundary between the former and the contemporary solution, as is the instance in Sopot. As the example of Malbork demonstrated, it is equally inappropriate to use technical and material measures that differ significantly from the original. A proper exemplification of the procedure is the work undertaken on the Gdańsk Główny train station's platforms. Both in the shelter on platform No. 1, created in the 1990s, and the shelter on platform No. 3, extended in 2013-2014, the contemporary pillars were given a form resembling the original, however simplified, making it possible to distinguish them. Simultaneously, the material and colour consistency with the historical shelters have been maintained there, which should be considered a beneficial outcome.

The preserved cast-iron platform shelters are a testimony to dynamic transformations in the European construction industry in the $2^{\text {nd }}$ half of the $19^{\text {th }}$ century. They also evidence a significant, unprecedented $19^{\text {th }}$-century inclination to erect buildings where structural elements, due to their slenderness and meticulous consideration of details, acquired an interesting artistic form. Their resistance to environmental factors ensured that their mainte- 
nance did not require significant financial expenditures over the years, making it possible for them to survive, often unaffected, until the present day. As remnants of construction technology and station architecture of the $19^{\text {th }}$ century, cast-iron platform shelters are now a valuable technical concept document. Nevertheless, even though historical objects' authenticity is not sufficiently valued among the Polish society [24, p. 9], it should be particularly protected by properly undertaken conservation works.

Translated by Michat Kwasek

\section{Acknowledgements}

Special appreciation to Marta Jedlikowska and Olga Broniewska from the Offices for Monuments Protection in Gdańsk and Sopot for their help

in collecting archival documentation and Professor Aleksander Piwek, for valuable factual comments.

\section{References}

[1] Załuski D., Dworce kolejowe. Śródmiejskie przestrzenie podróży, Wydawnictwo Politechniki Gdańskiej, Gdańsk 2010.

[2] Watkin D., Historia architektury zachodniej, Arkady, Warszawa 2001.

[3] Zomkowski S., Tramwajem przez Gdańsk, Wydawnictwo Sebastian Zomkowski, Gdańsk 2015.

[4] Rutkowski M., Powstanie pierwszych linii kolejowych w Królestwie Polskim, [in:] M. Proniewski, W. Czarnecki (red.), Obiekty kolejowe. Układy przestrzenne, architektura, elementy techniki, Wydawnictwo Wyższej Szkoły Finansów i Zarządzania, Białystok 2005, 39-47.

[5] Dylewski A., Historia kolei w Polsce, P.H.W. Fenix, Wierzchy Parzeńskie 2014.

[6] 150 lat kolei na ziemiach polskich, A.E. Kubicka (red.), Kolejowa Oficyna Wydawnicza, Warszawa 1995.

[7] Zamkowska S., Odbudowa i funkcjonowanie kolei polskich 1944 1949, Wydawnictwa Komunikacji i Łączności, Warszawa 1984.

[8] Foljanty K., Przekształcanie zabytkowych dworców i terenów kolejowych $w$ struktury wielofunkcyjne, "Architectus" 2016, nr 2(46), 65-78, doi: 10.5277/arc160205.

[9] Załuski D., Dworzec kolejowy w strukturze miasta: nowe szanse, [in:] D. Załuski (red.), Dworzec kolejowy w strukturze miasta, Urbanista, Warszawa 2006, 273-284.

[10] Addis W., 3000 years of design engineering and construction, Phaidon Press, London 2015.

[11] Dobraszczyk P., Meta-Ornament: Iron and the Railway Station in Britain, [in:] P. Dobraszczyk, P. Sealy (ed.), Function and fantasy. Iron architecture in the long nineteenth century, Routledge, Taylor \& Francis, New York-London 2016, 201-219.

[12] Wesołowski J., Od wozowni do katedry. Hala peronowa w architekturze dworców, t. 1: Historia. Konstrukcja, Wydawnictwo Politechniki Łódzkiej, Łódź 2014.

[13] Kwasek M., Piwek A., Lightweight glass and metal roof structures in the $19^{\text {th }}$ century. Architecture and construction, [in:] L. Małyszko, R. Tarczewski (ed.), XXII Lightweight Structures in Civil Engineering: contemporary problems. Monograph from XXII Scientific
Conference of IASS Polish Chapters, Wydawnictwo UWM, Olsztyn 2016, 31-36.

[14] Schmitt E., Handbuch der Architektur, T1. 4, Entwerfen, Anlage und Einrichtung der Gebäude, Hbd. 2, H. 4, Empfangsgebäude der Bahnhöfe und Bahnsteigüberdachungen (Bahnsteighallen u. -dächer), Leipzig 1911.

[15] Czapliński K., Dawne wyroby ze stopów żelaza, Dolnośląskie Wydawnictwo Edukacyjne, Wrocław 2009.

[16] Brych I., Sýkora M., Assessment of cast-iron columns using analytical models, "Applied Mechanics and Materials" 2016, Vol. 821, 782-788, doi: 10.4028/www.scientific.net/AMM.821.782.

[17] Kwasek M., Piwek A., Jankowski R., Study on $19^{\text {th }}$-century cast iron columns from the former financial office building in Kwidzyn, "MATEC Web of Conferences" 2018, Nr 219(3), 1-8, doi: 10.1051/ matecconf/201821902011.

[18] Gruszkowski W., Rozwój przestrzenny Gdańska, [in:] E. Cieślak (red.), Historia Gdańska, t. 4, Wydawnictwo Prawnicze LEX, Sopot 1998, 250-267.

[19] Fuglewicz S., Zabytki komunikacyjne - dziedzictwo ginace, [in:] S. Januszewski (red.), Dziedzictwo postindustrialne i jego kulturotwórcza rola, Fundacja Hereditas, Warszawa 2009.

[20] Skalimowski A., Tucholski Z., Modernistyczne wiaty i przystanki kolejowe Warszawskiego Węzła Kolejowego. O konieczności ochrony konserwatorskiej, "Ochrona Zabytków" 2010, nr 1-4, 73-84.

[21] Wesołowski J., Hala peronowa jako problem konserwatorski, "Technika Transportu Szynowego" 2014, nr 7-8, 17-26.

[22] Czapliński K., Gawron K., O żeliwnych elementach konstrukcyjnych i dekoracyjnych, "Przegląd Budowlany" 2011, nr 4, 56-59.

[23] Marcinkowski J., Różycki Z., Reinforcement of existingcast-iron structural elements by means of fiber reinforced composites, "Civil and Environmental Engineering Reports” 2016, nr 20(1), 37-45, doi: 10.1515/ceer-2016-0004.

[24] Kwaśniewski A., Polskie podejście do waloru autentyzmu zabytków architektury, [in:] E. Łużyniecka (red.), Dziedzictwo architektoniczne: rekonstrukcje i badania obiektów zabytkowych, Oficyna Wydawnicza PWr, Wrocław 2017, 6-22.

\section{Abstract \\ Conservation aspects of cast-iron platform shelters on the example of Vistula Pomerania railway stations}

Cast-iron shelters were used in the $19^{\text {th }}$ century as cheaper alternatives to large platform halls. Nevertheless, they were aesthetically distinguishable from later riveted solutions. Because of their durability and continuous utility, they were not the subject of disassembly, as numerous transport infrastructure objects have been in recent decades. This article aims to indicate proper conservation practices during construction works on cast-iron platform shelters. Nowadays, most frequently, they take place during the modernization of railroad stations. As presented in this text, the approach to conservation procedures can be significantly different. The paper investigates technical and architectural solutions of selected instances of cast-iron platform shelters in Vistula Pomerania. Some references to foreign designs are also presented. The analysis of literature and archival documentation of the project, as well as the field studies, enabled us to formulate conclusions - recommendations for the proper procedure in respect of this type of object. 
Cast-iron platform shelters ought to be preserved as the unique remnant of $19^{\text {th }}$-century architecture. It is recommended to use an adequately selected material during the works and to restore the artistic qualities of cast-iron structures by restoring their original paintings. The author also refers to the realization of new roofing created in the preserved historical objects' closest vicinity. Based on the illustrated instances, he recommends efforts to maintain consistency between new or reconstructed structures and authentic $19^{\text {th }}$-century ones. Simultaneously author emphasizes the necessity of avoiding the obliteration of the distinction between them. He drew attention to the challenges of repairing cast-iron pillars, giving examples of techniques that can be applied.

Key words: platform shelters, cast-iron construction, $19^{\text {th }}$-century architecture, monument conservation, cast-iron columns

\section{Streszczenie}

\section{Zagadnienia zwiazane z konserwacją żeliwnych wiat peronowych na przykladzie dworców Pomorza Nadwiślańskiego}

Żeliwne wiaty były stosowane w XIX w. jako tańsze odpowiedniki wielkich hal peronowych. Mimo to wyróżniały się swoją estetyką na tle późniejszych - nitowanych - rozwiązań. Ze względu na ich trwałość i ciągłą przydatność nie podlegały rozbiórkom jak wiele obiektów techniki transportowej w ostatnich dziesięcioleciach. Celem artykułu jest wskazanie dobrych praktyk konserwatorskich w trakcie prac budowlanych dotyczących żeliwnych wiat peronowych. Współcześnie mają one najczęściej miejsce przy modernizacji dworców kolejowych. Jak przedstawiono w niniejszym tekście, sposób podejścia do zabiegów konserwatorskich może być znacząco różny. W artykule przedstawiono wyniki badań rozwiązań technicznych oraz architektonicznych wybranych przykładów żeliwnych zadaszeń peronowych na terenie Pomorza Nadwiślańskiego. Przedstawiono także nawiązania do realizacji poza granicami Polski. Analiza literatury przedmiotu i archiwalnej dokumentacji projektowej, a także badania terenowe umożliwiły sformułowanie wniosków - rekomendacji dla właściwego postępowania przy tego typu obiektach.

Jako unikatowa pozostałość po architekturze XIX w. żeliwne wiaty peronowe powinny być bezwzględnie chronione. W trakcie prac wskazane jest stosowanie odpowiednio dobranego materiału, a także dążenie do przywrócenia żeliwnym wiatom ich walorów artystycznych poprzez odtworzenie pierwotnej kolorystyki. Autor artykułu odnosi się również do realizacji nowych zadaszeń, powstających w bezpośrednim sąsiedztwie zachowanych historycznych obiektów. Bazując na przedstawionych przykładach, rekomenduje dążenie do zachowania spójności nowych lub rekonstruowanych obiektów z autentycznymi realizacjami z XIX w. Jednocześnie podkreśla konieczność dbałości o to, by granica między nimi nie uległa zatarciu. Zwrócił uwagę na trudności, jakie mogą dotyczyć prac naprawczych przy żeliwnych słupach, podając przykłady technik możliwych do zastosowania.

Slowa kluczowe: wiaty peronowe, konstrukcja żeliwna, architektura XIX w., konserwacja zabytków, kolumny żeliwne 